\title{
The dilemma of creator and creation: Dr. Frankenstein vs. the Monster
}

\author{
Banu Erşanlı* \\ Department of Communication Design, Başkent University, Ankara, Turkey
}

\author{
Keywords \\ Dilemma \\ Creator \\ Creation \\ Relation \\ Received: 1 October 2018 \\ Accepted: 5 November 2018 \\ Published: 11 December 2018
}

\begin{abstract}
The purpose of this study is to analyze Frankenstein's monster created in the 18th century with the dilemma of creator-creation relation, under a gothic perspective. Within this context, gothic literature and gothic cinema will be mentioned in the first part of the study to describe the style of the novel. In the second part, the historical dynamics of the period will be explained, and mention the life of Mary Shelley and the process of creating the novel to help understand the novel better. The third part is dedicated to a historical and a visual analysis based on the samples from book illustrations, caricatures, theatre banners, and comic books, which involved characters of the novel throughout the illustration process.
\end{abstract}

(C) 2018 The Author(s). Published by TAF Publishing.

\section{ON THE CONCEPT OF GOTHIC}

The concept of Gothic was first used in history, with reference to Goth raids against Romans, meaning barbarism and primitiveness (Osmanoğulları, 2016; Wu, 2017). It identified the darkness, overbearingness and vandalism of the feudal order both positively and negatively; and it refers to an ongoing war between modern and classic, past and present (Tuncer, 2014). The name gothic is assumed to have been given by the Renaissance painter Raphael, who was famous for his devotion to classicism; and it is a changeable notion between the concepts of primitivism and civilization (Osmanoğulları, 2016). It is also an aesthetic style available in different branches of art $3 \mathrm{p} 0$; such as painting, cinema, literature, music, architecture, fashion, and theatre. Özkaracalar (2005), on the other hand, asserts that the word gothic is used to identify the period from Visigoth invasion and collapse of Roman Empire until Renaissance; and to apprehend the facts belonging to this age (p: 8).

The idea that accurate information can be obtained through intelligence was the common perspective prevailing in the 18th century Age of Enlightenment. Romanticism, on the other hand, emerged as a negative reaction against Enlightenment, which manifested itself not only politically but also in science and art. By means of exposing the abstract against what is tangible, it expressed the inconvenience felt for the undermining of humanity's and society's certain aspects (Azhar, 2015; Yavuz \& Geçikli, 2008). Gothic literature is a literary type emerged firstly in German, English and French literatures during Romantic period, with the appearance of fantastic elements; and occurred as a type of narration that involved horror and mystery, and supernatural heroes such as vampires or monsters created in laboratories (Yılmaz, 2006). By their nature, Gothic novels are observed to not reflect the characteristic of the period they belong to. It is also possible to suggest that they involve a sense of rebellion due to manifesting an anti-Enlightenment structure (Yavuz \& Geçikli, 2008).

Gothic literature usually involves a mysterious, scary old male character who lives in an old, partially ruined castle or mansion surrounded by threatening supernatural creatures; a vulnerable female character; and a third character who is in between good and evil (Osmanoğulları, 2016).

\footnotetext{
*corresponding author: Banu Erşanlı

†email: banu@baskent.edu.tr
} 
Even though gothic novels seem to give prominence to physical and psychological fear, mystery, supernatural entities, gloomy places such as abandoned buildings, castles, dungeons etc., secret passages, forests, wild nature, ruined monasteries, torture rooms, darkness, regression, insanity, prophecies, and curses; (Yavuz \& Geçikli, 2008) the main subject is actually the human and intelligence (Arargüç, 2016). Cruel people, bandits, maniacs, suffering femme fatales, wizards, vampires, werewolves, monsters, demons, ghosts, specters, and skeletons are extraordinary characters encountered in these novels (Yavuz \& Geçikli, 2008) . Urgan (2003) defined their purpose of gothic novel as "to cause intense excitement and to terrify the audience by means of creating an atmosphere full of horror, mystery and thrill; as well as using certain supernatural situations when necessary, such as ghost appearances or utterance of prophecies" (p: 109).

In gothic novels, the line between the good and evil is blurry (Arargüç, 2016) and it is also possible to propose that gothic novels are in the form of warnings in terms of handling issues; such as privacy invasion or revelation of a forbidden information (Arargüç, 2016). The first example of gothic literature is the novel named The Castle Of Otranto by Horace Walpole (Yllmaz, 2006). In 1764, the second edition of the novel was published after having added the subtitle of "A gothic story" (Özkaracalar, 2005).

With its huge narrative potential, cinema managed to establish a much stronger bond with novel, when compared with other branches of art. Almost any story narrated in a novel can be similarly projected on cinema screen. Although cinema is limited to a shorter period of narration, it has pictorical opportunities based on its visual narrative nature. In novel, on the other hand, the relationship between the story and the narrator is based on story materials; such as story arc, character, plot, and theme (Monaco, 2002). Besides, gothic cinema is mostly regarded as a subgenre of horror movies, which nourishes from science fiction, drama, mystery or adventure movies, too (Osmanoğulları, 2016).

According to Kale (2010), the relationship between literature and cinema, which have been in interaction for centuries, is rather based on the "adaptation of literary works to movies" (p: 274). Works of several authors; such as Ann Radcliffe, Horace Walpole, Matthew Gregory Lewis , Mary Shelley, Bram Stoker, and Edgar Allen Poe have been adapted to cinema for so long, which formed the basis for gothic cinema. Kemp (2014) describes the introduction of gothic genre with cinema as:

There were certain attempts to adapt gothic novels to movies in the first decades of cinema history, which did not happen until 1920s. The convention of gothic film was settled with the help of gothic novels from 18th and 19th centuries, and movies that used the dark and depressive atmosphere of German Expressionist films such as 'Der müde To d' by Fritz Lang and Nosferatu, a Symphony of Horror by F. W. Murnau. These movies showed the cinematic power of lighting and set design required to create the dark atmosphere of ruined chateaus occupied by bats and witches ( $\mathrm{p}$ : 88).

19th century gothic literature allowed the readers to identify themselves with anti-heroes. This was then followed by the introduction of these heroes on screen, which turned them into icons starring in various cinematic adaptation.

\section{MARY SHELLEY AS A NOVELIST}

Mary Wollstonecraft Godwin (Figure 1), who was born in 1797 as the daughter of William Godwin and Mary Wollstonecraft, married Percy Bysshe Shelley, who was one of the six greatest British romantic poets (Özdemir, 2004). Her father William Godwin was a writer known for his radical political views, while her mother Mary Wollstonecraft was an effective defender of women's rights (İsmayilov \& Sunal, 2013).

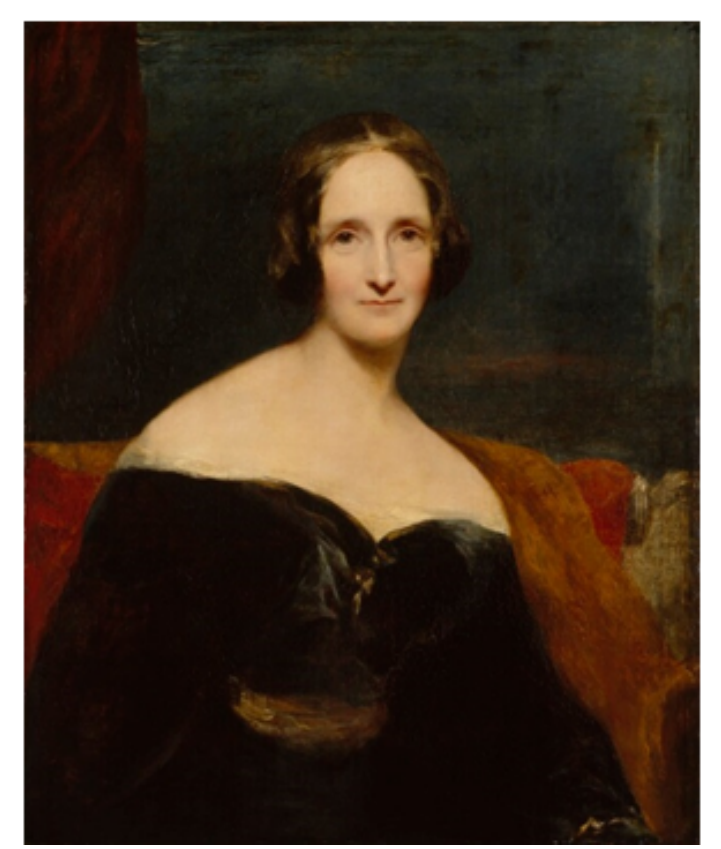

FIGURE 1. Mary Shelley's (1849) portrait, Londra National Portrait Gallery (Source: https://urlzs.com/5NFTV)

Mounseer Nongtonpaw is the first poem written by Mary Shelley at the age of 10 , which was published in 1807 by her father's publishing house.

The first edition of Shelley's novel Frankenstein or Modern Prometheus, which she wrote at the age of 19, was published anonymously due to living in a time where writing 
was not considered as an appropriate profession for women (Figure 2). Danacl (2011) explains the creation of the novel as: In 1816, Lord Byron, Dr. Polidori, Byron's lover, Mary Shelley and Percy Bysshe Shelley gathered in Geneva, where they told German horror stories to each other. Then, they decided to organize a story contest, which resulted in emergence of different stories. Lord Byron wrote a story that he added to the end of his poem Mazeppa; while Polidori wrote The Vampire which would become a classic in the following years. Among these, Shelley's novel was the only one to be completed and turned into a novel in history (p: 52).

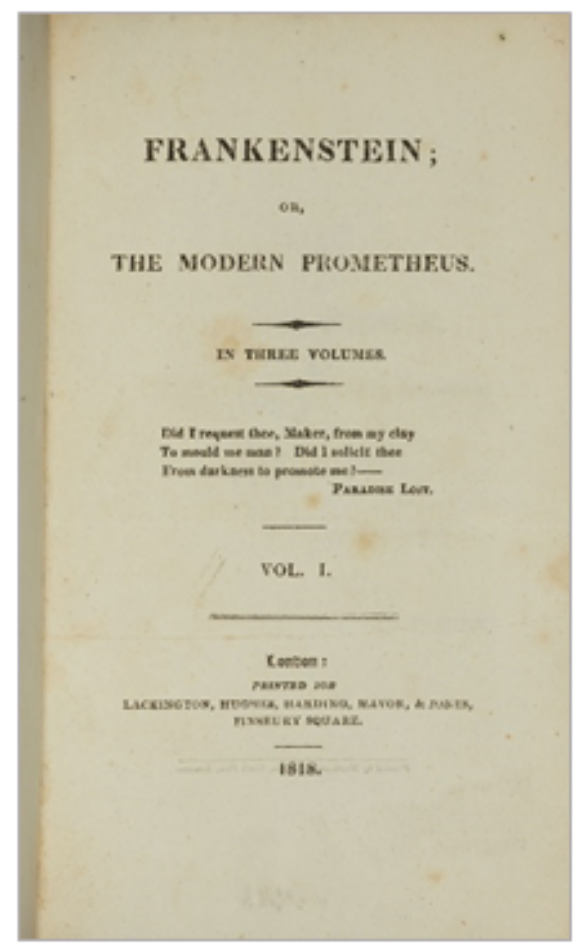

FIGURE 2. Frankenstein or the modern prometheus novel's first print (Source: https://urlzs.com/rGamV)

On the front page of the book, we can see a quote from the 10th book of Paradise Lost by John Milton, from the pages 743-745 (Figure 3): "Did I request thee. Maker, from my clay/To mould me Man, did I solicit thee/From darkness to promote me?"

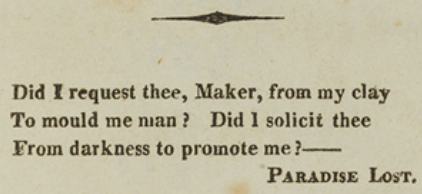

FIGURE 3. Section from Frankenstein or the modern prometheus novel's first print (Source: https://urlzs.com/rGamV)

Written in free verse, Paradise Lost is one of the most sig- nificant literary works of English literature; and it is considered a masterpiece in terms of giving the deepest and most detailed narrative on how Adam and Eve was expelled from paradise. Mary Shelley's quoting from Paradise Lost in her own work was no coincidence. At this point, interpretation of these two works in the context of intertextuality will be useful. In Frankenstein or Modern Prometheus, the monster with a tragic story, reveals similarities both with Adam and Devil. Expulsion of Adam from paradise and his dismissal by God is actually in parallel with the monster being dismissed by its creator.

Moreover, in the part where the monster talks to Dr. Frankenstein about the books he reads, he explains the relation between him and Adam \& Devil in Paradise Lost, with the following sentences: ... Like Adam, I was apparently united by no link to any other being in existence; but his state was far different from mine in every other respect. He had come forth from the hands of God a perfect creature, happy and prosperous, guarded by the especial care of his Creator; he was allowed to converse with and acquire knowledge from beings of a superior nature, but I was wretched, helpless, and alone. Many times I considered Satan as the fitter emblem of my condition, for often, like him, when I viewed the bliss of my protectors, the bitter gall of envy rose within me (Shelley, 2008).

According to Demirci (2006), revolting against the creator is an important indicator of revolting against God in religious context; against the father in family context; and against the degenerated so-called selfdom in social context (p: 62). According to this, the monster's feelings for its creator refer to an attempt of taking him as a father, which is regarded as God by the monster. Simultaneously, the monster becomes the child or the servant for its creator. Likewise, the struggle of the monster and Adam for being "good" is another similarity between these two characters. The similarity between the monster and devil, on the other hand, can be suggested given their desire to take revenge from their creators. However, both of them have the feeling of regret that comes after revenge.

When both stories are handled as a whole, the parallelism in the axis of common points and the story can be inferred easily: Both Paradise Lost by Milton and Frankenstein or Modern Prometheus by Shelley are stories of creation.

It is possible to see further references to Milton's Paradise Lost throughout the story. In the part where the things happened to the monster after running away from Frankenstein's house is told, the hut found by the monster while wandering around is described as: But I was enchanted by the appearance of the hut; here the snow and rain could not 
penetrate; the ground was dry; and it presented to me then as exquisite and divine a retreat as Pandemonium appeared to the demons of hell after their sufferings in the lake of fire (Shelley, 2008).

The Pandomenium mentioned here was used in John Milton's Paradise Lost to refer to the capital of hell. Throughout the book, Shelley establishes further intertextual relations between other books and works. It is possible to see occasional references or quotes from these works: Samuel Taylor Coleridge 's The Rime of the Ancyent Marinere (1834), Oliver Goldsmith 's The Vicar of Wakefield (1776), Lord Byron's Childe Harold's Pilgrimage (1816), Costantin François de Chasseboeuf, Volney Comte's The Ruins (1791), Plutarkhos 's Demosthenes Cicero, Goethe 's Die Leiden des Jungen Werthers (1774), Percy Bysshe Shelley's Mutability (1816) and Alastor (1816) poems, William Wordsworth's Tintern Abbey (Tintern Manastırı, 1798) and Ksenophon 's Anabaisis.

For that matter, it can be suggested that the first intertextuality about the novel is embodied within the novel itself. The novel is based on the struggle of an anonymous monster for socializing, who identifies as a human rather than a creature and thinks like one; as well as its isolation from other people as a social entity (Danacl, 2011). It continues with the story mentioned in Robert Walton's letters, which he wrote after running into Dr. Victor Frankenstein during a trip, and things happened to the doctor. According to Franco Moretti (2017), the monster is completely a manmade, collective and artificial creature which is not existent in nature (p: 108). The story where the conflict between Frankenstein, the creator who is an inventor-scientist, and the explorer-scientist Walton is narrated, is carried to a different temporal dimension when Victor Frankenstein starts to tell his childhood memories; and sometimes focuses on Walton's perspective and narration.

Although the story was developed out of Shelley's imagination, it is possible to suggest that the experiments on bioelectricity and Calvinism (Danacl, 2011) formed the fundamental ground of the novel. It is assumed that Giovanni Aldini and Luigi Galvani are the names Shelley was inspired by. In 1780, Galvani made studies about moving the muscles of a dead frog through electricity with an aim to move them by impulse and contractions. There are explanations and illustrations from this experiment available in his book entitled De Virbus Electricitatis In Motu Musculari Commentarus which was published in 1792 (Figure 4). Luigi Galvani's cousin Giovanni Aldini, on the other hand, took these experiments further and used steer and bull heads as experimental subjects.

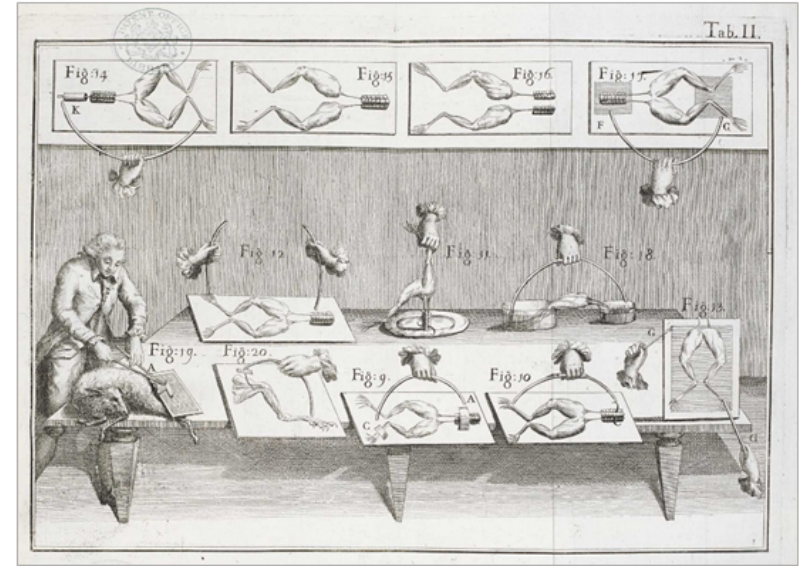

FIGURE 4. Illustration of the frog experiment performed by Luigi Galvani (Source: https://urlzs.com/hvQif)

There are several scientists known to have conducted studies on similar contexts in that period. Andrew Ure was one of these scientists who stood out with his experiments. Enactment of the Murder Act in England in 1751 paved the way for experiments to be conducted on dead bodies. Thanks to this law, Ure also carried out various studies on corpses and bodies and tried to resuscitate them through electricity (Figure 5).

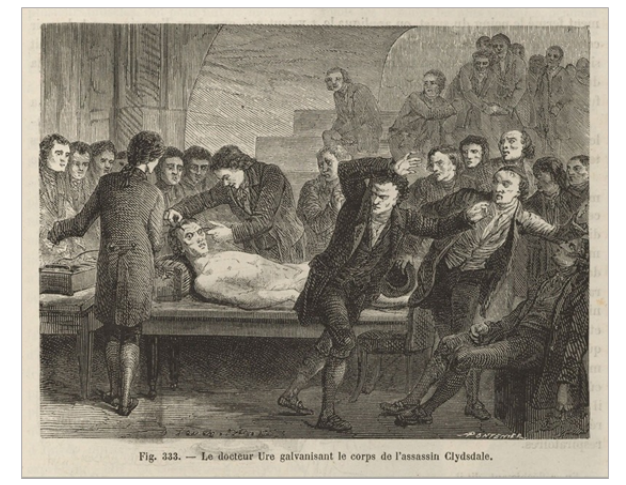

FIGURE 5. Illustration of the electrical experiment performed by Adrew Ure on Matthew Clydesdale (Source: https://urlzs.com/DCDP8)

Creating a living creature out of nothing is an obvious attempt to emulate God and involves a challenge; while the monster's superhuman powers refer to the transcendental aspect of the novel (Osmanoğulları, 2016). According to Ozer (1989), emulating God is regarded as a sin in terms of religion; while it is reflected as the primary aesthetic and ethical value in romantic literature ( $\mathrm{p}: 37$ ). Atayman (2006), on the other hand, makes the following comment about the ending of the story: Any artificial or scientific attempt to create a human has been regarded as a sinful crime since Mary Shelley's Frankenstein, in terms of interfering with God's work and attempting to create a second world; to such an extent that both the creator and the crea- 
ture could not get away from its consequences at the end (p: 137). The novel projects an anti-Enlightenment view in terms of illustrating the unrestrained development of science triggered by French Revolution and Industrial Revolution (Yavuz \& Geçikli, 2008). Being described as the fear of bourgeois civilization by Moretti (2017), Frankenstein is a freak concerning that the future will be as scary as himself (p: 105-106). According to Yücesoy (2007), what created the monster of Frankenstein was neither a curse from the past nor an inexplicable supernatural entity as in 18th century gothic stories; but the bourgeoisie itself where people attempt to create similar beings in the light of scientific developments ( $\mathrm{p}:$ 17). In the novel, we see that Shelley does not comply with the consistency standards of Enlightenment and prefers to write without rules by means of stepping out of the style, in order to reinforce the notion of freedom (Yavuz \& Geçikli, 2008). Being positioned right in the middle of English Romanticism, Shelley experienced various personal losses and identified herself with the feelings of loneliness and alienation. Within this context, it is possible to regard the loneliness and alienation of Frankenstein's monster as a metaphor representing the author's feelings. Today, it is estimated that there are only 500 accessible copies of the first edition of Frankenstein or Modern Prometheus. In 2013, Mary Shelley's manuscripts were transferred on a digital platform in cooperation with New York Public Library, Bodleian Library, Maryland Institute for Technology in Humanities, British Library, Huntington Library, Art Collection and Botanical Gardens, and Victoria \& Albert Museum.

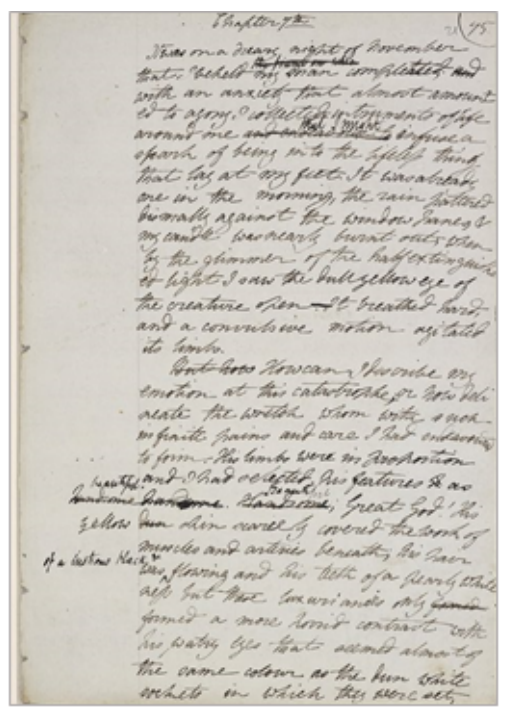

FIGURE 6. A page of Mary Sheley's handwriting from Frankenstein or the modern prometheus (Source: https://urlzs.com/KusLG)
The archive also contains the works of Percy Bysshe, William Godwin, and Mary Wollstonecraft, who are known to be the first author family of England, accessible on https://urlzs.com/eRqfS Although Mary Shelley became famous with Frankenstein or Modern Prometheus, she wrote other literary works, as well. Some of them are: Valperga (1823), The Last Man (1826), The Fortunes of Perkin Warbeck (1830), Lodore (1835), Falkner, A Novel (1837).

\section{Book Illustrations}

Each community has their own myths and adventures within them (Burkus, 2015). Being presented in a narrative form in literary texts, these adventures are sometimes accompanied by visual communication elements such as sketches, illustrations or pictures. According to Mendelsund (2015), while reading an illustrated book, the images help the reader to shape the things they see within their heads. Such an opportunity offer a different kind of experience and may direct the reader ( $p$ : 199). This is because that books are capable of offering a certain kind of freedom. While reading, the person is free to be mentally active; while at the same time gets involved in the creation of a narrative, in any way possible (Mendelsund, 2015). However, readers mostly like the changeability and unpredictability offered by the book and do not want to see things to be shown (Mendelsund, 2015).

Although this is the case for readers, some novels and literary works are much more suitable for illustration as a result of their sophisticated descriptions and the opportunities they offer. Despite the fact that there are various limitations - technical, personal, social - in the process of illustrating a text, all the drawings made for Frankenstein or Modern Prometheus facilitated the nourishment of the novel, as well as the enhancement of its intertextuality.

13 years after the anonymous publication of Frankenstein or Modern Prometheus, Mary Shelley's name as the author was included in the republishing in 1831; where various illustration, imaging, and visualizations were used in different editions in order to support the story visually. As Frankenstein's monster became an icon throughout the years, different artists produced different works on the depiction of this monster.

\section{Monster in Political Cartoons}

While the notion of caricature is defined as "thoughtprovoking and amusing picture which is processed steeply and based on any matter about humans and society", its most common and basic definition is "humor through sketches". The term comes from the verb "caricare" which 
means to attack (Senyapili, 2003). Arargüç (2016), who is a caricaturist, gives a comprehensive explanation for the term by saying "Caricature is an art of humor which captures the aspects of events, emotions and thoughts that are funny and contradict with what is natural and usual; and turns them into a humorous narratives through exaggerated drawings accompanied by texts" (Aygün, 2007). According to Selçuk (1979), on the other hand, caricature has become a strong branch of art due to certain reasons. Caricature is a common art, facing the public at any moment via press, cinema, television, posters and exhibitions. It conveys its message in the shortest and most striking way possible, without any trouble (Ozer, 1989). Within this context, it can be suggested that caricature has turned into an effective type of narrative which can be used socially or politically, revealing the characteristics of its time.

In parallel with the reproduction of newspapers and journals, and their transformation into an effective mass medium; the art of caricature also diverged from the art of painting and expanded, although they shared common stylistic grounds. The works of William Hogarth, the British painter and engraving master who is regarded as the pioneer of contemporary caricature, can be accepted as the first step in the process of recognition and widespread of caricature (Bayram, 2009). Emergence of humor papers, on the other hand, were first triggered by the Fischietto which was a paper published in Italy. There is no doubt that the developments occurring in printing techniques were also affective on the widespread of caricature. The inseparable relation between the art of caricature and politics varies de- pending on the place, time, conditions, and people (Turan, 2012).

With reference to the novel Frankenstein or Modern Prometheus, where emergence of the working class against bourgeoisie as an opposing force (Yücesoy, 2007), and the political concerns about a possible revolution are reflected; the 19th century characters Doctor Frankenstein and the monster are observed to have been emblematized and used in political caricatures. According to Moretti (2017), the monster struggles to move the social conflict and the violence outside the society and this conflict is between the "demon race" and "human race" (s: 106). According to this, the monster is now a part of the society, and the horror elements which were distant and not included until gothic literature is now situated right in the middle of the society, as a part of them. Besides, referring to monster's demands from Doctor Frankenstein as rather innocent, Moretti (2017) states that there is a "reformist/chartist" attitude in these demands (s: 109). In the novel the monster, who dreamt of blending in the society and admired the happy and peaceful life of neighbors, left each individual relationship with disappointment and isolation; and therefore, tried to solve this problem by asking for a partner from its creator. However, the monster's demand was declined due to its scary image and all the harm it had caused. As seen in Table 1, direct reflection of such an attitude by the monster inspired different artists to draw Frankenstein-themed caricatures in different papers and journals between 1833-1893, in an attempt to criticize and satirize the social and political movements of the time.

TABLE 1. List of Frankenstein themed caricatures published between 1833-1893

\begin{tabular}{|c|c|c|c|c|}
\hline & Name & Year & Artist & Newspaper/Magazine \\
\hline 1. & Frankenstein Creating Peers & 1832 & Robert Seymour & $\begin{array}{l}\text { McLean's Monthly Sheet of } \\
\text { Caricatures }\end{array}$ \\
\hline 2. & Reform Bill's First Step Amongst his Political Frankensteins & 1833 & James Parry & - \\
\hline 3. & A New Illustration of the Story of Frankenstein & 1843 & John Doyle & - \\
\hline 4. & The Irish Frankenstein & 1843 & Joseph Kenny Meadow & $\begin{array}{l}\text { Punch, or the London Chari- } \\
\text { vari }\end{array}$ \\
\hline 5. & The Russian Frankenstein and his Monster & 1854 & John Leech & $\begin{array}{l}\text { Punch, or the London Chari- } \\
\text { vari }\end{array}$ \\
\hline 6. & The New Frankenstein & 1862 & Henry Louis Stephans & Vanity Fair \\
\hline 7. & The Brummagem Frankenstein & 1866 & John Tenniel & $\begin{array}{l}\text { Punch, or the London Chari- } \\
\text { vari }\end{array}$ \\
\hline 8. & The Irish Frankenstein & 1869 & Matt Morgan & $\begin{array}{l}\text { The Tomahawk: A Saturday } \\
\text { Journal of Satire }\end{array}$ \\
\hline 9. & The American Frankenstein & 1873 & Frank Bellew & New York Daily Graphic \\
\hline 10. & The American Frankenstein & 1874 & Frank Bellew & New York Daily Graphic \\
\hline 11. & The Irish Frankenstein & 1882 & John Tenniel & $\begin{array}{l}\text { Punch, or the London Chari- } \\
\text { vari }\end{array}$ \\
\hline 12. & The Frankenstein of Hatfield and his Handiwork & 1893 & Thomas Fitzpatrick & Weekly Freeman \\
\hline
\end{tabular}


As classic literary texts became political myths, characters appearing in stories started to be included in caricatures in order to criticize the current political system. In order to represent unrestrained power and people, the word "Frankenstein", and thereby the monster metaphor was used in rewritten texts (Deniz, 2017).

\section{Monster on Scene}

Presumption! is the first theatre adaptation of Frankenstein, which was adapted by Peake in 1823, from Shelley's novel. The play was staged for the first time at British Opera House in London on July 28 1823, and was played for a total of 37 times. However, the starring actor Cooke played the monster more than 350 times in different adaptations. This way, Cooke went down in history as the first actor to play the monster. Shelley was also one of the audience to watch the play in London and left the hall quite pleased (Danacl, 2011). In its 29 July 1823 issue The London Morning Post, a British newspaper of the time, mentioned the play Presumption! and Thomas Potter Cooke's performance as:

A romance of peculiar interest... The efforts to relieve the serious action of the piece by mirth and music were generally successful, and the labours of Mr. Watson the composer we often loudly applauded. The acting was very grand. Wallack, as Frankenstein, displayed great feelinng an animation. T. P. Cooke as was tremendously appealing (Kabatchnik, 2017).

It must be also noted that the success of Presumption! enabled the republication of Mary Shelley's novel by her father William Godwin in 1823, as well as its illustration by more than one artist. The success of Cooke's performance as Frankenstein's monster in different plays led to the creation of an iconized image of this monster, even in the movie shot by Universal Studios in 1931 where the monster's image would become famous as a classic.

TABLE 2. List of Frankenstein themed theatres staged between 1823-1887

\begin{tabular}{|c|c|c|c|c|}
\hline & Name & Date & Writer & Place \\
\hline 1. & $\begin{array}{l}\text { Presumption; or, the Fate of } \\
\text { Frankenstein }\end{array}$ & 28 July 1823 & Richard Brinsley Peake & $\begin{array}{l}\text { English Opera House, London, } \\
\text { Great Britain }\end{array}$ \\
\hline 2. & $\begin{array}{l}\text { Frankenstein; or, The Demon of } \\
\text { Switzerland }\end{array}$ & 18 August 1823 & Henry M. Milner & $\begin{array}{l}\text { Royal Coburg Theatre, London, } \\
\text { Great Britain }\end{array}$ \\
\hline 3. & $\begin{array}{l}\text { Humgumption; or, Dr. Franken- } \\
\text { stein and the Hobgoblin of Hox- } \\
\text { ton }\end{array}$ & 1 September 1823 & - & $\begin{array}{l}\text { New Surrey Theatre, London, } \\
\text { Great Britain }\end{array}$ \\
\hline 4. & $\begin{array}{l}\text { Presumption; or, the Blue De- } \\
\text { mon }\end{array}$ & 1 September 1823 & - & $\begin{array}{l}\text { Davis's Amphitheatre, London, } \\
\text { Great Britain }\end{array}$ \\
\hline 5. & Another Piece of Presumption & 20 October 1823 & Richard Brinsley Peake & $\begin{array}{l}\text { Adelphi Theatre, London, Great } \\
\text { Britain }\end{array}$ \\
\hline 6. & $\begin{array}{l}\text { Frank-in-Steam; or the Modern } \\
\text { Promise to Pay }\end{array}$ & 13 December 1824 & - & $\begin{array}{l}\text { Olympic Theatre, London, Great } \\
\text { Britain }\end{array}$ \\
\hline 7. & Le Monstre et le Magicien & 10 June 1826 & John Kerr & $\begin{array}{l}\text { Theatre de la Porte Saint- } \\
\text { Martin, Paris, France }\end{array}$ \\
\hline 8. & $\begin{array}{l}\text { The Man and the Monster; or, } \\
\text { The Fate of Frankenstein }\end{array}$ & 3 July 1826 & Henry M. Milner & $\begin{array}{l}\text { Royal Coburg Theatre, London, } \\
\text { Great Britain }\end{array}$ \\
\hline 9. & $\begin{array}{l}\text { Les Filets de Vulcain; ou, La } \\
\text { Venus de Neuilly }\end{array}$ & 5 July 1826 & $\begin{array}{l}\text { Nicolas Brazier, Guil- } \\
\text { laume Dumersan, } \\
\text { Gabriel-Jules-Joseph } \\
\text { de Lurien }\end{array}$ & $\begin{array}{l}\text { Theatre des Varietes, Paris, } \\
\text { France }\end{array}$ \\
\hline 10. & Le Petit Monstre et l'escamoteur & 7 July 1826 & $\begin{array}{l}\text { Jules-Henri Vernoy de } \\
\text { Saint-Georges, Antoine- } \\
\text { Jean-Baptiste Simonnin }\end{array}$ & $\begin{array}{l}\text { Theatre de la Gaite, Paris, } \\
\text { France }\end{array}$ \\
\hline 11 & $\begin{array}{l}\text { La Peche de Vulcain; ou, l'ile des } \\
\text { fleuves }\end{array}$ & July 1826 & $\begin{array}{l}\text { Claude-Louis-Marie } \\
\text { de Rochefort-Lucay, } \\
\text { Esperance-Hippolyte } \\
\text { Lassagne, Mathurin- } \\
\text { Joseph Brisset }\end{array}$ & $\begin{array}{l}\text { Theatre du Vaudeville, Paris, } \\
\text { France }\end{array}$ \\
\hline 12. & Le Presomteueux & 11 July 1826 & - & $\begin{array}{l}\text { Theatre de M. Comte, Paris, } \\
\text { France }\end{array}$ \\
\hline 13. & $\begin{array}{l}\text { Les Filets de Vulcain; ou, le } \\
\text { lendemain d'un success }\end{array}$ & 15 July 1826 & P. Carmouche & $\begin{array}{l}\text { Theatre de la Porte Saint- } \\
\text { Martin, Paris, France }\end{array}$ \\
\hline
\end{tabular}


TABLE 2. Continue..

\begin{tabular}{|c|c|c|c|c|c|}
\hline & Name & Date & Writer & & Place \\
\hline 14. & Le Monstre et le physicien & 3 August 1826 & - & & - \\
\hline 15. & $\begin{array}{l}\text { The Monster and Magician; or, } \\
\text { The Fate of Frankenstein }\end{array}$ & 9 October 1826 & John Kerr & & $\begin{array}{l}\text { New Royal West London The- } \\
\text { atre, London, Great Britain }\end{array}$ \\
\hline 16. & $\begin{array}{l}\text { Frankenstein; or, The Model } \\
\text { Man }\end{array}$ & 26 December 1849 & $\begin{array}{l}\text { William } \\
\text { Brough }\end{array}$ & Robert & $\begin{array}{l}\text { Adelphi Theatre, London, Great } \\
\text { Britain }\end{array}$ \\
\hline 17. & Le Monstre et le magicien & 1851 & - & & $\begin{array}{l}\text { Theatre de l'Ambigu Comique, } \\
\text { Paris, France }\end{array}$ \\
\hline 18. & Le Monstre et le magicien & 22 June 1861 & Ferdinand Dugue & & $\begin{array}{l}\text { Theatre de l'Ambigu Comique, } \\
\text { Paris, France }\end{array}$ \\
\hline 19. & $\begin{array}{l}\text { Frankenstein; or, The Vampire's } \\
\text { Victim }\end{array}$ & 24 December 1887 & Richard Henry & & Gaiety Theatre, Dublin, Ireland \\
\hline
\end{tabular}

\section{Comic Books}

Based on the conveyance of a story through drawings, comic books are created with the help of both graphic arts, painting, and literature. According to Alsaç; being a story narrative through sketches, comic books have their own history consisting of their linear and narrative features (Coşkun, Çikrikci, \& Topkaya, 2017), which is completely isolated from sociological relations. Pictures, new structures, themes, dynamic lines, characters, frames, fiction, drawing techniques, and speech bubbles (Eğribel, 2012) are basic factors comprising the authentic world of comic books. It draws the strength of media from the ability to shape people's visions of world, and to be the primary source of ideas and opinions (Burton \& Fazlası, 2008). Similar to the books existing in media industry, comic books also establish a bond with its precedents and posteriors, which directly involves intertextuality.

Comic books enable the readers to see while reading the message, and the characters are not just the strokes of a pen; but rather move in different frames and scenes. These are drawn in verbal frames, not visual, and then the scenes are pieced together by the reader, and these passages turn into a reasonable narrative collectivity (Mendelsund, 2015).

Following the Frankenstein story which was published with illustrations under the name Frankenstein Comics in 1940 was then followed by hundreds of works published with the same theme. These publications, which were created by different artists, are listed in Table 3 in detail, and then provided in a visual catalog prepared. A total of 76 different comic books and comic series published in 1940-2018 were reached, and found that these publications have 318 different issues. Purpose of the visual catalog is to reveal the evolution of Frankenstein's monster in parallel with technologic and social developments throughout the years; as well as to identify the impact of the artists on perception and presentation of the monster.

TABLE 3. List of Frankenstein themed comic books published between 1940-2018

\begin{tabular}{|c|c|c|c|c|c|}
\hline & Name & Year & Publisher & Issue & Cover Design \\
\hline 1. & Frankenstein Comics & $1940-1954$ & Prize & 33 & Dick Briefer \\
\hline 2. & Classics Illustrated \#26 Frankenstein & $1945-1971$ & Classics Illustrated & 20 & - \\
\hline 3. & The Journal of Frankenstein & 1959 & New World Enterprises & 3 & - \\
\hline 4. & Castle of Frankenstein & $1962-1975$ & Gothic Castle Publishing & 25 & $\begin{array}{l}\text { Larry Ivie (s. 1, 3, 5) } \\
\text { Robert Adranga (s. 2) } \\
\text { Lee Wanagiel (s. 4) } \\
\text { Frank Brunner (s. 15, 17) } \\
\text { Ken Kelly (s. 16, 18) } \\
\text { Maelo Cintron (s. 19, 20) } \\
\text { Marcus Boas (s. 21) } \\
\text { Bhob Stewart (s. 22) } \\
\text { Tom Maher (s. 24) } \\
\text { Russ Jones (s. 25) }\end{array}$ \\
\hline 5. & Frankenstein & 1964 & Dell & 4 & $\begin{array}{l}\text { Vic Prezio (s. 1) } \\
\text { Tony Tallarico (s. 2, 3, 4) }\end{array}$ \\
\hline 6. & Curse of Frankenstein Horror of Dracula & 1964 & James Warren & 1 & - \\
\hline 7. & Frankenstein, Jr. and the Impossibles & 1966 & Gold Key & 1 & Hanna Barbera \\
\hline 8. & Castle of Frankenstein Annual & 1967 & Gothic Castle & 1 & Russ Jones \\
\hline 9. & Frankenstein Jr Menace of the Heartless Monster & 1968 & Whitman & 1 & Hanna Barbera \\
\hline
\end{tabular}


TABLE 3. Continue..

\begin{tabular}{|c|c|c|c|c|c|}
\hline & Name & Year & Publisher & Issue & Cover Design \\
\hline 10. & The Monster of Frankenstein & $1973-1975$ & Marvel Comics Group & 18 & $\begin{array}{l}\text { Mike Ploog (s. 1-6) } \\
\text { John Buscema (s.7, 8) } \\
\text { Tom Palmer (s. 9) } \\
\text { Gil Kane (s. 10, 15) } \\
\text { Bob Brown (s.11) } \\
\text { Val Mayerik }(s .12,13,18) \\
\text { Ron Wilson (s.14, 16) } \\
\text { Ed Hannigan (s. 17) }\end{array}$ \\
\hline 11. & Das Monster Von Frankenstein & 1973 & Marvel & 1 & Gil Kane \\
\hline 12. & Frankenstein & 1973 & Now Age Books & 1 & Nardo Cruz \\
\hline 13. & Frankenstein & 1976 & Corgi & 1 & Tom Barling \\
\hline 14. & $\begin{array}{l}\text { Frankenstein A Portfolio by Berni Wright- } \\
\text { son }\end{array}$ & 1977 & Tyrannosauros Press & 3 & Berni Wrightson \\
\hline 15. & Frankenstein Classic & 1977 & One-Shot comic books & 1 & - \\
\hline 16. & $\begin{array}{l}\text { A Story of Dracula the Wolfman and } \\
\text { Frankenstein }\end{array}$ & 1979 & Marvel & 1 & Neal Adams \\
\hline 17. & Frankenstein & 1983 & Marvel Illustrated Novel & 1 & Bernie Wrightson \\
\hline 18. & Frankenstein & 1989 & Eternity & 3 & - \\
\hline 19. & Frankenstein & 1990 & Malibu & 1 & Patrick Olliffe \\
\hline 20. & Doctor Frankenstein's House of 3-D & 1992 & 3D Zone & 1 & Dick Briefer \\
\hline 21. & The Lost Frankenstein Pages & 1993 & Apple Press & 1 & Bernie Wrightson \\
\hline 22. & Universal Monsters Frankenstein & 1993 & Dark Horse & 1 & Den Beauvais \\
\hline 23. & Frankenstein or the Modern Prometheus & 1994 & Caliber Press & 1 & Charles Yates \\
\hline 24. & Frankenstein & 1994 & Miller Illustrated Novel & 1 & Bernie Wrightson \\
\hline 25. & Mary Shelley's Frankenstein & 1994-1995 & Topps Comics & 8 & $\begin{array}{l}\text { Rafael Kayanan } \\
\text { Tim Bradstreet }\end{array}$ \\
\hline 26. & Frankenstein Dracula War & 1995 & Topps Comics & 3 & Mike Mignola \\
\hline 27. & Megaton Man vs. Forbidden Frankenstein & 1996 & Fiasco & 1 & - \\
\hline 28. & Castle of Frankenstein Yearbook & 2000 & Druktenis Publishing & 1 & Larry Ivie \\
\hline 29. & $\begin{array}{l}\text { Castle of Frankenstein Presents: New Ad- } \\
\text { ventures of Frankenstein }\end{array}$ & 2001 & Druktenis Publishing & 11 & Rock Spine Mountfort \\
\hline 30. & Frankenstein Mobster & 2003-2004 & Image & 16 & $\begin{array}{l}\text { Mark Wheatley (s. 0-7) } \\
\text { Adam Hughes (s. 0) } \\
\text { Mike Wieringo (s. 1) } \\
\text { Micheal Avon Oeming (s. 2) } \\
\text { Jerry Ordway (s. 3) } \\
\text { Scott Morse (s. 4) } \\
\text { Angelo Torres (s. 5) } \\
\text { Alex Nino Cencept (s. 6) } \\
\text { Bernie Wrightson Concept (s. 7) }\end{array}$ \\
\hline 31. & Doc Frankenstein & $2004-2007$ & Burlyman Entertainement & 12 & $\begin{array}{l}\text { Geoff Darrow } \\
\text { Steve Skroce }\end{array}$ \\
\hline 32. & Electric Frankenstein & 2004 & Dark Horse & 1 & Sal Canzonieri \\
\hline 33. & Essential Monster of Frankenstein & 2004 & Marvel & 1 & Boris Vallejo \\
\hline 34. & Monster Mayhem Series Frankenstein & 2005 & Dead Dog Comics & 2 & Jerry Beck \\
\hline 35. & Witchblade vs. Frankenstein Monster War & 2005 & Top Cow & 2 & $\begin{array}{l}\text { Joyce Chin } \\
\text { Vitor Ishimura }\end{array}$ \\
\hline 36. & Frankenstein & 2005 & Puffin Books & 1 & - \\
\hline 37. & Seven Soldiers Frankenstein & 2005 & Dc Comics & 4 & Doug Mahnke \\
\hline 38. & Frankenstein & 2006 & Norma Editorial & 1 & Patrick Olliffe \\
\hline 39. & The Shadow of Frankenstein & 2006 & Dark Horse Novel & 1 & - \\
\hline 40. & Bride of Frankenstein Pandora's Bride & 2007 & Dark Horse & 1 & Elizabeth Hand \\
\hline 41. & Igor Fixed by Frankensteins & 2007 & SLG & 1 & Chris Grine \\
\hline 42. & Kolchak Tales Frankenstein Agenda & 2007 & Moonstone & 6 & $\begin{array}{l}\text { Dave Ulanski (s. 1) } \\
\text { Bob Layton (s. 1, 2) }\end{array}$ \\
\hline 43. & Frankenstein & 2008 & Classical Comics & 1 & $\begin{array}{l}\text { Jason Cobley } \\
\text { Declan Shalvey }\end{array}$ \\
\hline 44. & Graphic Classics: Frankenstein & 2008 & Barron's & 1 & Penko Gelev \\
\hline 45. & Frankenstein & 2008 & Dark Horse & 1 & Bernie Wrightson \\
\hline
\end{tabular}


TABLE 3. Continue..

\begin{tabular}{|c|c|c|c|c|c|}
\hline & Name & Year & Publisher & Issue & Cover Design \\
\hline 46. & Frankenstein & 2008 & Stone Arch Books & 1 & Dennis Calero \\
\hline 47. & Dean Koontz's Frankenstein & 2008 & Dabel Brothers Production & 6 & $\begin{array}{l}\text { Breeth Booth } \\
\text { Arthur Suydam }\end{array}$ \\
\hline 48. & Jingle Belle Santa Claus vs. Frankenstein & 2008 & Top Cow & 2 & Stephanie Gladden \\
\hline 49. & Frankenstein Mobster & 2009 & IDW Publishing & 1 & Mark Wheatley \\
\hline 50. & Frankenstein & 2009 & Everest Yayınları & 2 & Marion Mousse \\
\hline 51. & Frankenstein's Womb & 2009 & Warren Ellis & 2 & Marek Oleksicki \\
\hline 52. & Frankenstein & 2009 & NTV Yayınları & 1 & Declan Shalvey \\
\hline 53. & Dean Koontz's Frankenstein & 2009 & Dynamite Entertainement & 1 & Breeth Booth \\
\hline 54. & Angel I & 2009 & IDW Publishing & 1 & John Byrne \\
\hline 55. & Angel II & 2010 & IDW Publishing & 1 & John Byrne \\
\hline 56. & Frankenstein & 2010 & Campfire Classic & 1 & Naresh Kumar \\
\hline 57. & Dean Koontz's Frankenstein & 2010 & Dynamite Entertainement & 5 & $\begin{array}{l}\text { Breeth Booth (s. 1) } \\
\text { Scott Cohn (s. 2-5) }\end{array}$ \\
\hline 58. & Frankenstein & 2010 & Classic Pop-Up Tales & 1 & Anthony Williams \\
\hline 59. & $\begin{array}{l}\text { Dick Briefer's Frankenstein: The Chilling } \\
\text { Archives of Horror Comics }\end{array}$ & 2010 & IDW Publishing & 1 & Alex Toth \\
\hline 60. & Frankenstein Creatures of the Unknown & 2011 & Flashpoint & 3 & Doug Mahnke \\
\hline 61. & Frankenstein Agent of S.H.A.D.E. & $2011-2013$ & DC Comics & 17 & $\begin{array}{l}\text { Alberto Ponticelli } \\
\text { Wayne Faucher }\end{array}$ \\
\hline 62. & Frankenstein Alive Alive & 2012 & IDW Publishing & 4 & Bernie Wrightson \\
\hline 63. & $\begin{array}{l}\text { Return of the Monsters Phantom Detective } \\
\text { vs Frankenstein }\end{array}$ & 2012 & Moonstone & 1 & Andrew Froedge \\
\hline 64. & Criminal Macabre Eyes of Frankenstein & 2013 & - & 4 & Michelle Madsen \\
\hline 65. & Gris Grimly's Frankenstein & 2013 & - & 1 & Gris Grimly \\
\hline 66. & Doc Frankenstein & 2014 & - & 1 & Steve Skroce \\
\hline 67. & Frankenstein Alive Alive & 2014 & IDW Publishing & 1 & Bernie Wrightson \\
\hline 68. & Madame Frankenstein & 2014 & Image & 8 & $\begin{array}{l}\text { Megan Levens (s. 1) } \\
\text { Joelle Jones (s. 2-7) } \\
\text { Nick Filardi (s. 2-7) }\end{array}$ \\
\hline 69. & Dean Koontz's Frankenstein & 2015 & Dynamite Entertainement & 6 & Andres Ponce \\
\hline 70. & Frankenstein Underground & 2015 & Dark Horse & 6 & $\begin{array}{l}\text { Dave Stewart (s. 1) } \\
\text { Mike Mignola (s.1-5) }\end{array}$ \\
\hline 71. & Joe Frankenstein & 2015 & IDW Publishing & 8 & Graham Nolan \\
\hline 72. & Van Helsing vs. Frankenstein & 2016 & Zenescope Entertainement & 20 & $\begin{array}{l}\text { Richard Ortiz (s. 1a, 3a) } \\
\text { Gregbo Watson (s. 1b) } \\
\text { Andrea Meloni (s. 1c) } \\
\text { Jason Metcalf (s. 1d, 2a, 3b, 4d, 5b) } \\
\text { Mike Mahle (s. 2b) } \\
\text { Michael Dooney (s. 2c) } \\
\text { Noah Salonga (s. 2d) } \\
\text { Jamie Tyndall (s. 3c) } \\
\text { Sami Kivela (s. 3d) } \\
\text { Paolo Pantalena (s. 4a) } \\
\text { David Lorenzo Riveiro (s. 4b) } \\
\text { Joe Pekar (s. 4c) } \\
\text { Manuel Preitano (s. 5a) } \\
\text { Renato Rei (s. 5c) } \\
\text { Leonardo Colapietro (s. 5d) }\end{array}$ \\
\hline 73. & Dracula Marries Frankenstein & 2017 & Papercutz & 1 & Jon Buller \\
\hline 74. & $\begin{array}{l}\text { Sherlock Frankenstein and the Legion of } \\
\text { Evil }\end{array}$ & $2017-2018$ & Dark Horse & 8 & David Rubin \\
\hline 75. & Frankenstein or the Modern Prometheus & 2017 & Caliber Press & 1 & $\begin{array}{l}\text { Charles Yates } \\
\text { Eric Jackson }\end{array}$ \\
\hline 76. & Frankenstein Alive, Alive! & 2018 & IDW Publishing & 1 & Bernie Wrightson \\
\hline
\end{tabular}




\section{CONCLUSION}

Being based on a freak recreated by Victor Frankenstein at the risk of withstanding the divine power, which is a redefinition of humanity's greatest fear, Frankenstein or Modern Prometheus is a literary and classic novel preserving its popularity even today. Although the novel is attempted to be categorized as a work of gothic literature, the number of science-fictional elements embodied within the story are considerably high. The novel, which is based on a man facing the possibility of being destroyed by his own cre- ation, also involves certain notions; such as creation myths, existence, and desire to be God, and therefore became a legend and prodigious. The story was narrated based on the mutual and opposite relationship between the creator Frankenstein and the monster; and it is possible to see that Frankenstein actually detests and wants to kill the creature he created. By creating a monster stronger than him, the doctor actually gives life to a murderer who later becomes the reason of his death as well as his beloved ones.

\section{REFERENCES}

Arargüç, M. F. (2016). Mimari bir tarzdan edebi bir türe: Gotik. Güzel Sanatlar Enstitüsü Dergisi, 5(36), 245-257.

Atayman, V. (2006). Postmodern kurtaricılar. Istanbul, Turkey: Donkisot Guncel Yayinlar.

Aygün, S. (2007). Anadolu üniversitesi eğitim karikatürleri müzesi seramikleri. Anadolu Üniversitesi Sanat ve Tasarım Dergisi, 3(3), 10-23.

Azhar, M. (2015). The concept of religious democracy as a new political philosophy for countries with moslem predominant. Journal of Advances in Humanities and Social Sciences, 1(1), 19-28. doi:https://doi.org/10.20474/jahss1.1.3

Bayram, Y. (2009). Türkiye'de siyasi karikatürün yeri ve 11 nci cumhurbaşkanlığı seçimine ilişkin siyasi karikatürlerin çözümlenmesi. Cumhurbaskanlıgı Secimine, 6(1), 107-123.

Burkus, D. (2015). Yaratıcılık mitleri. Istanbul, Turkey: Nobel Akademik Yayincilik.

Burton, G., \& Fazlası, G. (2008). Çev: Nefin dinç. Istanbul, Turkey: Görünenden Fazlası. Yeni Alan Yayıncılık.

Coşkun, K., Çikrikci, Ö., \& Topkaya, Y. (2017). Is birth order really important in peer relationship? A grounded theory approach. Cogent Education, 4(1), 45-67. doi:https://doi.org/10.1080/2331186x.2017.1296537

Danacı, F. (2011). Korkunun canavarları. Istanbul, Turkey: Kalkedon Yayınları.

Demirci, T. T. (2006). Korku sinemasının psikanalizi. Istanbul, Turkey: Es Yayınları.

Deniz, D. (2017). Politik karikatürlerde kadının temsili: 1950 seçimleri ve nesneleştirilen kadın. Karabük Üniversitesi Sosyal Bilimler Enstitüsü Dergisi, 7(2), 490-511. doi:https://doi.org/10.14230/joiss476

Eğribel, E. (2012). Çizgi roman olayı ve toplum. İstanbul Üniversitesi Sosyoloji Dergisi, 3(3), 1-44.

İsmayilov, E. K., \& Sunal, G. (2013). "frankenstein ya da modern prometheus" romanının sinemaya uyarlanması. Çankırı Karatekin Üniversitesi Sosyal Bilimler Enstitüsü Dergisi, 4(1), 199-222.

Kabatchnik, A. (2017). Blood on the stage, 1600 to 1800: Milestone plays of murder, mystery, and mayhem. Rome, Italy: Rowman \& Littlefield.

Kale, Ö. (2010). Edebiyat sinema ilişkisi. Uluslararası Sosyal Araștırmalar Dergisi, 3(14), 266-275.

Kemp, P. (2014). Sinemanın tüm öyküsü. Istanbul, Turkey: Hayalperest Yayınları.

Mendelsund, P. (2015). Okurken ne goruruz. Istanbul, Turkey: Metis.

Monaco, J. (2002). Bir film nasıl okunur? Sinema, medya ve mültimedya dünyası. Istanbul, Turkey: Oğlak Yayınları.

Moretti, F. (2017). Mucizevi gostergeler. Istanbul, Turkey: Metis.

Osmanoğulları, F. (2016). Gotik film: Bir çerçeve oluşturma denemesi ve house of usher. Sine Filozofi, 1(1), 17-37.

Özdemir, E. (2004). Frankenstein'ın yazarı" mary shelley'nin romancılığı. Istanbul, Turkey: İstanbul Bilgi Üniversitesi Yay.

Ozer, A. (1989). Karikatur sanatı ogretimi. E-Kurgu Journal, 6(6), 175-179.

Özkaracalar, K. (2005). Gotik. Istanbul, Turkey: Leyla ile Mecnun Yayıncılık.

Selçuk, M. K. (1979). Analysis, development and testing of a fixed tilt solar collector employing reversible vee-trough reflectors and vacuum tube receivers. Solar Energy, 22(5), 413-426. doi:https://doi.org/10.1016/0038-092x(79)90170-1

Senyapili, O. (2003). Karikatur. Ankara, Turkey: Odtu.

Shelley, M. (2008). Frankenstein. Cambridge, UK: Oxford University Press.

Tuncer, S. (2014). Gotik ve feminist anlatinin buluşmasi. Litera(15), 125-135.

Turan, M. (2012). Gazetelerde yayinlanan siyasi karikatürlerin göstergebilimsel çözümlemesi: 2011 genel seçimleri örneği. Selcuk Iletisim, 7(2), 121-138. 
Urgan, M. (2003). Ingiliz edebiyatı tarihi. Ankara, Turkey: Yapı Kredi Yayınları.

Wu, A. A. (2017). A study on learning achievement of integrated songs of Chinese history dynasties into Chinese language teaching at third grade in junior college. International Journal of Humanities, Arts and Social Sciences, 3(5), 192-196. doi:https://doi.org/10.20469/ijhss.3.20001-5

Yavuz, M. E., \& Geçikli, K. (2008). Gotik romanda aydinlanma karşitliği. Sosyal Bilimler Dergisi, 32(1), 171-188.

Yılmaz, M. (2006). Modernizmden postmodernizme sanat. Istanbul, Turkey: Ütopya.

Yücesoy, V. Ö. (2007). Korku edebiyatı (gotik edebiyat) ve türk romanındaki örnekleri (Unpublished master thesis). Istanbul University, Fatih, Turkey. 